\title{
MEKANISME PENCEGAHAN KERUGIAN DAN HAK NASABAH TERKAIT PENGGUNAAN KARTU ANJUNGAN TUNAI MANDIRI (ATM)*
}

\author{
Oleh : \\ I Putu Surya Budhi Utama Wintara** \\ Ni Ketut Supasti Dharmawan*** \\ Ni Putu Purwanti ${ }^{* * * *}$ \\ Program Kekhususan Hukum Bisnis Fakultas Hukum Universitas
Udayana
}

\begin{abstract}
ABSTRAK :
Penggunaan Anjungan Tunai Mandiri (ATM) dapat memudahkan konsumen/nasabah dalam melakukan transaksi pada Bank. Namun disisi lain dapat pula merugikan nasabah yang dapat disebabkan oleh adanya kesalahan maupun kerusakan pada mesin Anjungan Tunai Mandiri (ATM) tersebut. Tujuan penulisan ini yaitu: untuk menganalisis bagaimanakah pengaturan hak nasabah pengguna Anjungan Tunai Mandiri (ATM) berdasarkan Undang-Undang Nomor 10 Tahun 1998 Tentang Perubahan Atas Undang-Undang Nomor 7 Tahun 1992 Tentang Perbankan dan Undang-Undang Nomor 8 Tahun 1999 Tentang Perlindungan Konsumen dan mekanisme yang dilakukan pihak bank untuk mencegah kerugian nasabah terkait penggunaan ATM. Penelitian ini menggunakan metode hukum empiris, dengan pendekatan Perundang-undangan dan Pendekatan Fakta. Hasil studi menunjukkan bahwa pengaturan hak nasabah bank terkait penggunaan ATM secara umum mengacu pada Pasal 4 UndangUndang Nomor 8 Tahun 1999 Tentang Perlindungan Konsumen dan secara khusus pada Pasal 29 ayat 4 Undang-Undang Nomor 10 Tahun 1998 Tentang Perubahan Atas Undang-Undang Nomor 7 Tahun 1992 Tentang Perbankan yang pada intinya mengatur bahwa nasabah memiliki hak mendapatkan informasi lengkap dan jelas dari pihak bank. Sedangkan mekanisme yang dilakukan pihak bank untuk mencegah kerugian nasabah berkaitan dengan penggunaan mesin ATM dengan pemberian sosialisasi dan edukasi serta pemantauan langsung terhadap nasabah dan memberikan
\end{abstract}

\footnotetext{
"makalah ilmiah ini merupakan inti sari dari skripsi.

**I Putu Surya Budhi Utama Wintara adalah mahasiswa Fakultas Hukum Universitas Udayana. Korespondensi: esbe94@gmail.com

***Ni Ketut Supasti Dharmawan, adalah dosen Fakultas Hukum Universitas Udayana. Korespondensi: arasswk@yahoo.com

****Ni Putu Purwanti adalah dosen Fakultas Hukum Universitas Udayana.

Korespondensi: putu_purwanti@unud.ac.id
} 
ganti rugi terhadap nasabah apabila terjadi kesalahan oleh pihak bank.

\title{
Kata Kunci: Perlindungan Hukum, Nasabah, Anjungan Tunai Mandiri (ATM)
}

\begin{abstract}
:
The use of an Automatic Teller Machine (ATM) can facilitate consumers / customers in making transactions with the Bank. But on the other hand it can also harm the customer which can be caused by an error or damage to the Automatic Teller Machine (ATM). The purpose of this paper is: to analyze how the customer rights regulation of Automatic Teller Machines (ATM) is based on Law Number 10 of 1998 concerning Amendments to Law Number 7 of 1992 concerning Banking and Law Number 8 of 1999 concerning Consumer Protection and mechanism by the bank to prevent customer losses related to the use of ATMs. This study uses empirical legal methods, with the statute approach and the Fact Approach. The results of the study indicate that the regulation of bank customer rights related to the use of ATMs generally refers to Article 4 of Act Number 8 of 1999 and specifically in Article 29 paragraph 4 of Act Number 10 of 1998 concerning Amendments to Law Number 7 of 1992 concerning Banking, in essence, stipulates that customers have the right to get complete and clear information from the bank. While the mechanism carried out by the bank is to prevent customer losses related to the use of ATM machines by providing socialization and education as well as direct monitoring of customers and providing compensation to customers in the event of an error by the bank.
\end{abstract}

Keywords: Legal Protection, Client, Automatic Teller Machine (ATM)

\section{PENDAHULUAN}

\subsection{Latar Belakang}

Bank sendiri telah menjadi kerabat dalam melakukan berbagai jenis transaksi seperti melakukan pengiriman uang, pembayaran, penagihan, maupun guna kepentingan investasi. Adapun fungsi Bank antara lain sebagai lembaga yang menjadi wadah dalam keuangan bagi sebuah badan usaha, lembaga pemerintahan, lembaga swasta, ataupun milik perorangan. Selain menjadi wadah penyimpanan dana, Bank pun bisa menjadi 
tempat dalam bertransaksi keuangan. Melalui lembaga tersebut dana dari bank dapat/bisa disalurkan kembali dana yang sudah terkumpul tersebut kepada masyarakat melalui perantara hukum perkreditan. ${ }^{1}$ Dengan adanya perkembangan teknologi dan informasi yang pesat, dunia perbankan dapat menggunakan Teknologi Informasi (TI) dalam bidang perbankan untuk memaksimalkan pelayanan terhadap nasabahnya. Salah satu contoh perkembangan teknologi informasi yang diberikan oleh Bank adalah Anjungan Tunai Mandiri (ATM) yang berasal dari singkatan Automatic Teller Machine. ATM dapat berperan sebagai pengganti teller yang dapat melayani berbagai transaksi perbankan. ${ }^{2}$ Dengan adanya ATM masyarakat dipermudah untuk melaukan transaksi yang membutuhkan jumlah yang cukup besar, dengan itu dapat mengurangi risiko yang terjadi apabila masyarakat mengalami kehilangan ataupun menjadi korban perampokan.

ATM juga dapat mengakibatkan masalah bagi penggunanya. Berbagai macam masalah yang terdapat pada ATM dapat diakibatkan oleh kesalahan pengguna maupun kesalahan mesin dari ATM itu sendiri. Masalah-masalah tersebut dapat dilihat seperti tertelannya kartu ATM yang dimiliki oleh nasabah, pemblokiran kartu ATM yang disebabkan karena kesalahan nasabah maupun karena kesalahan yang terjadi pada mesin Anjungan Tunai Mandiri (ATM). Gagalnya melakukan transaksi oleh nasabah dikarenakan jaringan atau koneksi satelit yang buruk karena transaksi tersebut bersifat online sehingga merugikan pengguna ATM tersebut. Adapun dalam melakukan transaksi penarikan, adanya kesalahan yang terjadi pada mesin

${ }^{1}$ Sentosa Sembiring, 2012, Hukum Perbankan Edisi Revisi, Cetakan Ketiga, CV. Mandar Maju, Bandung. h. 15

2 Ismail, 2010, Manajemen Perbankan, Kencana, Jakarta, h. 174. 
ATM tidak mengeluarkan sebanyak nominal yang diinginkan namun telah terdebet sebanyak nominal yang diinginkan oleh nasabah tersebut. Masalah-masalah tersebutlah yang dapat mengurangi kepercayaan nasabah dan mengganggu penggunapengguna ATM tersebut.

Adapun pengertian dari perlindungan konsumen di dalam Undang-Undang No. 8 Tahun 1999 tentang Perlindungan Konsumen yaitu berbagai upaya yang menjamin adanya kepastian hukum untuk memberikan perlindungan terhadap nasabah/konsumen, maka dengan itu dapat disimpulkan bahwa konsumen mendapatkan hak-haknya untuk dilindungi atas masalah-masalah yang terjadi terhadap konsumen perbankan yang menggunakan dan sebagai pengguna dari Anjungan Tunai Mandiri atau yang disingkat sebagai ATM pada khususnya. Antara lain juga agar mengetahui apakah pihak Bank dalam hal ini sebagai pelaku usaha mampu memberikan perlindungan kepada nasabah-nasabahnya yang mengalami permasalahan dalam menggunakan ATM atas dirugikan hak-haknya atau tidak.

\subsection{Rumusan Masalah}

1. Bagaimanakah pengaturan hak nasabah pengguna ATM berdasarkan Undang-Undang Nomor 10 Tahun 1998 Tentang Perubahan Atas Undang-Undang Nomor 7 Tahun 1992 Tentang Perbankan dan Undang-Undang Nomor 8 Tahun 1999 Tentang Perlindungan Konsumen?

2. Bagaimanakah mekanisme yang dilakukan pihak bank untuk mencegah kerugian nasabah terkait penggunaan kartu maupun mesin ATM? 


\subsection{Tujuan}

Berdasarkan latar belakang diatas, adapun penulisan ini bertujuan yaitu untuk mengetahui bagaimanakah perlindungan hukum diatur didalam hukum positif Indonesia bagi nasabah Pengguna ATM dan untuk mengetahui upaya yang diberikan oleh bank terhadap konsumen agar mengetahui dan mendapatkan hak-haknya bila terjadi kerugian dalam penggunaan mesin maupun transaksi yang melibatkan ATM.

\section{ISI MAKALAH}

\subsection{Metode Penulisan}

Penulisan hukum empiris yang digunakandalam penulisan ini. Yang dimaksud dalam metode tersebut yaitu hukum yang dikonsepkan sebagai suatu fakta empiris yang dimana dapat dilihat didalam kehidupan sehari-hari atau secara nyata. Dengan itu pendekatan masalah yang sedang diteliti menggunakan sifat hukum yang benar atau sesuai dengan yang ada didalam lingkungan masyarakat. Karakteristik pada penelitian hukum empiris ini dapat terlihat pada sifat empirisnya dimana penelitian lapangan sebagaimana yang dilakukan oleh peneliti ilmu sosial menjadi rujukan. ${ }^{3}$ Penelitian terhadap hukum empiris memakai data primer dan data sekunder. Data sekunder yang terdapat didalam pengkajian hukum empiris adalah suatu bahan hukum, data sekunder tersebut di atas digunakan sebagai data awal dan kemudian secara bersekala didukung bersama data primer. Kemudian data primer dapat dilihat dari suatu penelitian di lapangan, kemudian data tersebut digabung, ditelah, serta dianalisis.

3Ade Saptomo, 2009, Pokok-Pokok Metodelogi PenelitIan Hukum Empiris Murni, Penerbit Universitas Trisakti, Jakarta, h. 39. 
Pendekatan dalam penulisan ini antara lain merupakan pendekatan Fakta (The Fact Approach), dan melalui Perundang-Undangan (Statue Approach) dengan adanya pendekatan didalam penelitian, penelitian akan mendapatkan informasi dari berbagai aspek mengenai isu yang sedang dicoba untuk dicari jawabannya. ${ }^{4}$ Adapun berbagai data yang digunakan dalam penulisan ini adalah data primer dan data sekunder. Data Primer merupakan suatu yang didapatkan secara aktual dari sumber ditempat kejadian baik itu melalui responden maupun pemberi informan. Data yang didapat untuk memberi pengertian pada bahan hukum primer, seperti suatu halnya perancangan dalam undang-undang, hasil dari penelitian, literatur, maupun pendapat para ahli merupakan data sekunder. ${ }^{5}$ Teknik pengambilan data dari penulisan merupakan Teknik wawancara. Wawancara dilakukan melalui cara mengajukan beberapa daftar pertanyaan yang diajukan secara sistematis. Adapun responden yang akan diwawancara antara lain responden di Bank Mandiri Denpasar.

\subsection{Hasil dan Pembahasan}

2.2.1. Pengaturan Hak Nasabah Pengguna ATM Berdasarkan Undang-Undang Nomor 10 Tahun 1998 Tentang Perubahan Atas Undang-Undang Nomor 7 Tahun 1992 Tentang Perbankan dan Undang-Undang Nomor 8 Tahun 1999 Tentang Perlindungan Konsumen

Nasabah bank sebagai pengguna ATM yang mengalami masalah kerugian seperti kartu tertelan, dana yang tidak muncul pada saat melakukan pengambilan/penarikan dan atau rekening

\footnotetext{
${ }^{4}$ Fakultas Hukum Universitas Udayana, 2013, Pedoman Pendidikan Fakultas Hukum Universitas Udayana, Denpasar, h. 80.

${ }^{5}$ Amiruddin \& H. Zainal Asikin, 2004, Pengantar Metode Penelitian Hukum, RajaGrafindo Persada, Jakarta, h. 119
} 
yang terdebet sendiri tanpa sepengetahuan nasabah atau konsumen bank tersebut, maka nasabah memerlukan perlindungan hukum dari Undang-undang tentang Perbankan, pada Pasal 29 ayat (4) Undang-Undang Perbankan yang menyebutkan "Demi suatu kepentingan untuk nasabah, bank wajib menjelaskan informasi terhadap suatu timbulnya akibat kerugian dalam transaksi nasabah yang dilakukan melalui bank" dimana pada bunyi dari pasal tersebut diketahui masih belum memuat perlindungan hukum secara terperinci terhadap nasabah. Pasal tersebut belum memberikan informasi yang lengkap yang dimana bagi kepentingan nasabah/konsumen yang melarang merugikan. Dalam Surat Edaran Nomor 14 / 17 / DASP / 2012 pada 7 Juni 2012 atas Perubahan Surat Edaran Bank Indonesia No. 11/10/DASP/2009 13 April 2009 perihal terhadap Kegiatan APMK, bahwa bank wajib harus menyampaikan informasi lengkap kepada pemegang APMK atau yang disebut nasabah maupun konsumen, yang meliputi:

1. Tata cara terhadap pengguna APMK dan berbagai kelengkapan fasiitas yang terdaat dalam kartu tersebut dan berbagai macam hal yang akan timbul bagi konsumen./nasabah terebut;

2. Hak-hak dan kewajiban bagi pengguna APMK, yaitu:

a. Nasabah dilarang memberikan nomor penting atau PIN kartu ATM tersebut kepada orang lain dan selalu berhati-hati dalam bertransaksi pada mesin ATM yag berada di Bank maupun diluar Bank;

b. Pertanggung jawaban dan Hak bagi pengguna ATM terhadap banyaknya suatu hal yang berdampak kerugikan terhadap nasabah dan/atau pemberi kartu, yang disebabkan karena adanya duplikat 
kartu, kesalahan oleh mesin penerbit, maupun hal yang dapat terjadi lainnya;

c. Prosedur maupun resiko bila nasabah ATM tidak berkeinginan lagi menggunakan kartu tersebut;

d. Bebagai hal dan banyaknya dana maupun anggaran yang dikenakan; dan

e. Prosedur penyajian terhadap aduan dalam hal memiliki hubungan bagi nasabah bank dan estimasi tempo penanganan laporan.

Terdapat dua hal yang perlu diperhatikan oleh pengguna ATM dalam pengunaan ATM, yaitu penggunaan dari segi teknis dan penggunaan dari segi yuridis. Permasalahan secara teknis yaitu berdasarkan tata cara pemakaian kartu ATM pada mesin ATM yang dapat berakibat hilangnya sejumlah uang nasabah dikarenakan kesalahan yang dibuat oleh nasabah itu sendiri. Berdasarkan hasil wawancara dengan salah satu staff Kantor Cabang Pembantu Bank Mandiri Gatot Subroto Denpasar, beliau menyebutkan bahwa dalam hal kesalahan yang terjadi adalah akibat dari ketidak hari-hatian nasabah, maka pihak bank tidak menanggung kerugian yang dialami nasabah tersebut (Wawancara tanggal 20 Maret 2017).

Undang-Undang Nomor 8 Tahun 1999 tentang Perlindungan Konsumen mampu dijadikan acuan sebagai dasar perlindungan untuk konsumen ataupun konsumen yang mengalami kerugikan dan meminta kedaulatannya tersebut. Dapat dilihat bahwa nasabah pada suatu bank atau nasabah pengguna ATM adalah merupakan konsumen yang dilindungi oleh Undang-Undang Perlindungan Konsumen tersebut. Dalam suatu kegiatan yang dilakukan oleh konsumen maupun nasabah dapat 
terjadi kerugian didalam penggunaan ATM yang sedang digunakan oleh nasabah tersebut sehingga timbulnya suatu kerugian bagi nasabah maupun konsumen pengguna ATM, kerugian yang bukan dikarenakan kesalahan dari nasabah pengguna ATM tersebut dapat diganti oleh pihak bank karena kewajiban itu sudah diatur didalam Undang-Undang Nomor 8 Tahun 1999 Tentang Perlindungan Konsumen dalam Pasal 7 huruf $f$ dan $g$ yaitu:

f. Memberikan ganti rugi atas kerugian yang diakibatkan dari suatu barang maupun jasa yang diberikan.

g. Bertanggung jawab atas barang maupun jasa yang diberikan apabila tidak seperti/sesuai dengan perjanjiannya tersebut.

Dapat dilihat juga secara tegas perlindungan hukum yang didapatkan oleh nasabah sudah diatur sesuai pada Pasal 4 huruf e Undang-Undang No. 8 Tahun 1999 Perlindungan Konsumen disebutkan secara jelas halnya : "hak untuk memperoleh advokasi, perlindungan, dan upaya penanganan kasus perkara perlindungan konsumen secara benar. ${ }^{6}$

\subsection{2. mekanisme yang dilakukan pihak bank untuk mencegah kerugian nasabah terkait penggunaan kartu maupun mesin ATM}

Bank Mandiri memiliki upaya-upaya dimana hal tersebut dapat mencegah kerguian yang dialami oleh nasabahnya tersebut. Menurut Ibu Ratna Sri Andiyani, Bank Mandiri sudah melakukan prosedur-prosedur keamanan yang dimana prosedur tersebut bertujuan untuk menjaga kerahasiaan akun pribadi nasabahnya

${ }^{6}$ A.A.Ngurah Rai Suarjaya Di Putra dan Cokorde Dalem Dahana, 2016, "Perlindungan Hukum Terhadap Rekening Nasabah Bank dalam Perjanjian Penggunaan Anjungan Tunai Mandiri (ATM) pada Bank Negara Indonesia (BNI) Cabang Teuku Umar Denpasar", Jurnal Fakultas Hukum Universitas Udayana. 
dan keamanan saat bertransaksi maupun disaat menggunakan mesin ATM. Pada awal pembukaan rekening tabungan nasabah sudah dapat memiliki kartu ATM yang dimana pegawai costomer service sebagai pelayan pertama nasabah tersebut menjelaskan bagaimana cara menggunakan fungsi ATM dan cara bertransaksi yang benar. Menurut Ibu Ratna Sri Andiyani, Bank mandiri juga berupaya memberi informasi kepada Nasabah terhadap hal penipuan yang dialami saat menggunakan dan bertransaksi melalui ATM seperti berikut :

a. Penipuan yang menggunakan modus seolah-olah nasabah memenangkan hadiah, dimana nasabah dijebak seakanakan mereka mendapatkan hadiah yang akan diberitahu oleh penipu menggunakan pesan elektronik. Nasabah diwajibkan mentransfer sejumlah dana yang telah ditentukan oleh penipu. Kemudian setelah dana diterima oleh penipu, penipu trsebut tidak lagi dapat dihubungi.

b. Pelaku penipuan akan seolah membantu nasabah yang kesulitan dalam melakuka transaksi di ATM, apabila korban telah masuk perangkap, pelaku akan meminta PIN korban untuk membantu melakukan transaksi, kemudian pelaku akan menyuruh korban untuk menelfon call center palsu yang bertujuan untuk menguras isi rekening korban/nasabah. (wawancara tanggal 20 Februari 2018)

Berdasarkan wawancara kepada salah satu staff Bank Mandiri Kantor Cabang Denpasar, beberapa upaya perlindungan terhadap nasabah dan tips diberikan oleh Bank Mandiri pengguna kartu ATM agar lebih berhati-hati dan lebih waspada terhadap penipuan yang terjadi dalam menggunakan ATM sebagai berikut : 
a. Jangan pernah memberikan kartu ATM terhadap orang lain atau orang yang tidak dikenal.

b. Jangan pernah memberikan nomor PIN kartu ATM anda kepada orang lain atau orang yang tidak dikenal, baik melalui telepon atau memberinya kepada orang yang terlihat seperti pegawai bank maupun mengaku seseorang dari pihak yang berwajib.

c. Jangan menuliskan nomor kartu anda dimanapun yang bersangkutan dengan kartu anda.

d. Secara bersekala melakukan pembaharuan PIN pada kartu ATM anda.

e. Saat melakukan transaksi di ATM usahakan selalu menutupi layar maupun papan tombol pin agar tidak terlihat oleh orang sekitar.

f. Bila kartu ATM anda hilang ataupun tertelan saat melakukan transaksi sebagiknya jangan panik dan segeralah melapor ke call center bank (mandiri) ataupun datang ke kator cabang bank mandiri terdekat untuk melakukan pelaporan dan pemblokiran untuk menghindari resiko-resiko buruk yang terjadi.

g. Lebih meningkatkan kewaspadaan kepada orang yang tidak diketahui ataupin mencurigakan yang secara spontan ingin memberi bantuan saat anda melakukan transaksi di ATM.

h. Tidak terpengaruh terhadap hadiah dari oknum yang tidak valid identitasnya, baik melalui berupa telpon maupun SMS, yang meminta kepada nasabah untuk mengirim sejumlah dana ke nomor rekening tertentu yang tidak jelas..

i. Jangan pernah memperlihatkan uang di dalam area ATM atau di tempat terbuka. 
j. Jika anda merasa diikuti atau diawasi saat bertransaksi di ATM oleh orang yang mencurigakan, pergilah tempat aman atau berusaha mencari petugas berwajib yang sedang bertugas.

k. Jangan ke ATM, apabila anda merasakan keraguan dalam melakukan transaksi atau penarikan pada lokasi tersebut. (wawancara tanggal 20 Februari 2018)

\section{PENUTUP}

\subsection{Kesimpulan}

1. Pengaturan hak nasabah bank terkait penggunaan kartu maupun mesin ATM secara umum mengacu pada Pasal 4 Undang-Undang Nomor 8 Tahun 1999 Tentang Perlindungan Konsumen yang meliputi: Hak yang diberikan atas kenyamanan konsumen, Hak konsumen untuk didengar, Hak untuk mendapat informasi yang benar, Hak untuk mendapat advokasi, Hak konsumen untuk mendapatkan pembinaan dan pendidikan konsumen, Hak untuk mendapat pelayanan yang benar dan jujur, Hak untuk mendapatkan konpensasi dan pada Pasal 29 ayat 4 Undang-Undang Nomor 10 Tahun 1998 Tentang Perubahan Atas Undang-Undang Nomor 7 Tahun 1992 Tentang Perbankan yang pada intinya bank berkewajiban memberikan dan menyediakan informasi terkait kemungkian adanya hal kerugian yang dialami dalam bertransaksi oleh konsumen/nasabah yang dilaksanakan di bank.

2. mekanisme yang dilakukan pihak bank untuk mencegah kerugian terhadap nasabah berkaitan dengan penggunaan mesin ATM meliputi: Pemberian sosialisasi dan edukasi, 
Pemberian informasi kepada nasabah atas kemungkinan timbulnya penipuan atau terhadap adanya penipuan, pemantauan melalui kamera CCTV, melakukan pembaharuan system pada mesin ATM serta pemberian ganti rugi terhadap nasabah manakala apabila terjadi kesalahan dari mesin ATM maupun dari pihak bank.

\subsection{Saran}

1. Hendaknya Bank Mandiri secara berkesinambungan terus menerus mensosialisasikan dan menginformasikan kepada para nasabah maupun kepada pegawai bank terkait ketentuan yang berkaitan dengan hak-hak konsumen, kewajiban konsumen, dan aturan-aturan hukum mengenai perlindungan hukum terhadap konsumen apabila terjadi kerugian terhadap konsumen.

2. Diharapkan agar Bank Mandiri Denpasar lebih memberikan sosialisasi terhadap nasabah baru agar lebih mengerti cara menggunakan kartu maupun mesin ATM agar terhidar dari segala macam kerugian maupun tindakan penipuan untuk meminimalisir kerugian yang dialami oleh nasabah Bank Mandiri Denpasar. 


\section{DAFTAR PUSTAKA}

\section{Buku-buku :}

Ade Saptomo, 2009, Pokok-Pokok Metodelogi Penelitian Hukum Empiris Murni, Penerbit Universitas Trisakti, Jakarta.

Amiruddin \& H. Zainal Asikin, 2004, Pengantar Metode Penelitian Hukum, RajaGrafindo Persada, Jakarta

Ishaq, 2009, Dasar-dasar Ilmu Hukum, Sinar Grafika, Jakarta.

Ismail, 2010, Manajemen Perbankan, Kencana, Jakarta.

Sembiring Sentosa, 2012, Hukum Perbankan Edisi Revisi, Cetakan Ketiga, CV. Mandar Maju, Bandung.

Fakultas Hukum Universitas Udayana, 2013, Pedoman Pendidikan Fakultas Hukum Universitas Udayana, Fakultas Hukum, Denpasar.

\section{Jurnal Ilmiah:}

A.A.Ngurah Rai Suarjaya Di Putra dan Cokorde Dalem Dahana, 2016, "Perlindungan Hukum Terhadap Rekening Nasabah Bank dalam Perjanjian Penggunaan Anjungan Tunai Mandiri (ATM) pada Bank Negara Indonesia (BNI) Cabang Teuku Umar Denpasar", Jurnal Fakultas Hukum Universitas Udayana.

Addilan Restu Ahsani dan Abdul Ghofur Anshori, 2008, "Perlindungan hukum terhadap nasabah pengguna kartu anjungan tunai mandiri (ATM) pada Bank Nagari Padang menurut Undang-undang No.10 tahun 1998 tentang perbankan" Jurnal Fakultas Hukum Universitas Gadjah Mada.

Ali Murdiat, 2013, "Perlindugan Hukum Nasabah Pegguna Elektronik Banking Dalam Sistem Hukum Indonesia" Jurnal Fakltas Hukum Universitas Sam Ratulangi.

\section{Peraturan Perundang-Undangan :}

Undang-Undang No. 10 Tahun 1998 Tentang Perubahan Atas Undang-Undang Nomor 7 Tahun 1992 Tentang Perbankan,

Undang-Undang No. 8 Tahun 1999 Tentang Perlindungan Konsumen. 